\title{
Suppression of Phytophthora Blight in Sweet Pepper Depends on Biochar Amendment and Soil Type
}

\author{
Nathan Shoaf and Lori Hoagland ${ }^{1}$ \\ Department of Horticulture and Landscape Architecture, Purdue University, \\ 625 Agriculture Mall Drive, West Lafayette, IN 47907
}

\author{
Daniel S. Egel \\ Department of Botany and Plant Pathology, Purdue University, 4369 North \\ Purdue Road, Vincennes, IN 47591
}

Additional index words. soil pH, microbial activity, nitrogen availability, chlorophyll content, microbial inoculants

\begin{abstract}
Phytophthora blight has become one of the most serious threats to the vegetable industry. Managing this disease is challenging, because the oomycete pathogen responsible, Phytophthora capsici, can move rapidly through crop fields, has a wide host range, is resistant to many commonly used fungicides, and produces resilient spores that can survive in soil for up to $\mathbf{1 0}$ years. Recent studies have demonstrated that biochar amendments can suppress infection by many soil-borne pathogens-indicating that these amendments could have the potential to help control phytophthora blight. In this study, greenhouse trials were conducted to determine whether two commercially available biochar amendments could suppress $P$. capsici infection in sweet bell pepper (Capsicum annuиm) using three naturally infested field soils. Soil biological and chemical assays were conducted to evaluate whether potential changes induced by biochar amendments were correlated with suppressive activity. Amending soil with a biochar product that included a proprietary mix of beneficial microorganisms and enriched substrates resulted in lower soil $\boldsymbol{P}$. capsici abundance in all soils, and lower percent root infection in two of the soils tested. This product also resulted in higher soil $\mathrm{pH}$, and lower soil nitrogen availability and leaf chlorophyll content. The other biochar product did not suppress $\boldsymbol{P}$. capsici, and had few effects on soil chemical and biological properties. Results of this study indicate that some commercially available biochar amendments have the potential to help mediate phytophthora blight, but further trials are needed to confirm that suppressive effects will be observed in field trials. Additional research is also recommended to identify the mechanisms regulating biochar-mediated suppression of phytophthora blight to develop products that can reliably suppress soil-borne diseases in the field.
\end{abstract}

Worldwide vegetable production valued at over $\$ 1$ billion each year is threatened by phytophthora blight (Lamour et al., 2012). This devastating disease is caused by $P$. capsici, a soil-borne oomycete pathogen that can infect a wide variety of crops in the Solanaceae, Curcurbitaceae, Fabaceae (Babadoost and Zitter, 2009; Erwin and Ribeiro, 1996; Hausbeck and Lamour, 2004), and 23 other plant families (Granke et al., 2012; Kousik et al., 2012). Under ideal environmental conditions, phytophthora blight can result in complete crop loss, and prevent further

Received for publication 28 Oct. 2015. Accepted for publication 1 Mar. 2016.

This work was supported by Purdue Agriculture Research Programs and the Indiana State Department of Agriculture-Specialty Crop Block Grant Program.

We thank Rob Eddy for assistance with greenhouse experiments, Kevin Gibson for contributing biochar, and Judy Santini for assistance with statistical analyses.

${ }^{1}$ Corresponding author. E-mail: 1hoaglan@purdue. edu. vegetable production in severely infected fields (Babadoost and Zitter, 2009; Hausbeck and Lamour, 2004; Kousik et al., 2012). Mature fruit can also be infected before harvest, but symptoms do not become discernible until fruit is received by processing plants and retailers (Jupe et al., 2013; Lamour et al., 2012), resulting in crop rejection and additional loss of revenue (Kousik et al., 2011). Finally, disposal of infected and sporulating plant material is costly which creates further problems for growers (Erwin and Ribeiro, 1996; Lamour et al., 2012).

Effectively managing phytophthora blight is challenging because dispersal of sporangia via irrigation or rain water results in rapid movement of inoculum around crop fields, and the pathogen can kill plants quickly making chemical control difficult (Erwin and Ribeiro, 1996; Granke et al., 2012). Crop rotation is ineffective because of the pathogen's broad host range and ability to produce spores that can remain dormant in soil for up to 10 years (Hausbeck and Lamour, 2004). Currently, the most effective strategies include cultural practices that reduce soil moisture, planting disease-resistant cultivars, and monitoring fields regularly so fungicides can be applied as soon as symptoms appear (Ristaino and Johnston, 1999). However, these strategies are becoming increasingly less effective, because $P$. capsici frequently develops virulent races that can overcome crop resistance (Ristaino et al., 1997), and many populations are now resistant to most commonly used fungicides (Hausbeck and Lamour, 2004; Kousik et al., 2011, 2012). Alternative strategies are needed to prevent further loss from this devastating disease.

Recently biochar has been suggested as an alternative disease management option (Elad et al., 2011; Jaiswal et al., 2014; Kammann and Graber, 2015; Lehmann et al., 2011). Biochar is a highly stable, carbon-rich product derived from pyrolysis, a process of thermally decomposing biomass at 300 to $600{ }^{\circ} \mathrm{C}$ under partial or complete exclusion of oxygen with little $\mathrm{CO}_{2}$ produced during the production process (Lehmann et al., 2006; Singh et al., 2010). Biochar amendments have been reported to suppress development of diseases caused by several soilborne pathogens, including Fusarium oxysporum (Elmer and Pignatello, 2011; Matsubara et al., 2002), Rhizoctonia solani (Jaiswal et al., 2014), Ralstonia solanacearum (Nerome et al., 2005), and Phytophthora cinnamomi and Phytophthora cactorum (Zwart and Kim, 2012). Peach replant disease, which is attributed to a complex of soil-borne pathogens as well as several abiotic soil factors, has also been alleviated by biochar amendment (Atucha and Litus, 2015). However, the mechanisms facilitating biochar-mediated disease suppression are not well understood, and suppressive effects could depend on the pathosystem and type of biochar applied (Graber et al., 2015). Biochar is made from a variety of feedstocks and produced using different pyrolysis conditions which can dramatically alter its physical and chemical properties (Amonette and Joseph, 2009; Downie et al., 2009). Differences in these properties have been demonstrated to alter biochar's subsequent effects on soil quality and crop productivity (Mukome et al., 2013; Novak et al., 2009), and also have the potential to affect its suppressive activity. Many commercially available products are amended with beneficial microbial inoculants which also has the potential to affect the suppressive activity of biochar amendments.

The objectives of this study were to determine whether two commercially available biochar amendments could suppress phytophthora blight, and determine if suppression was correlated with changes in soil biological and chemical properties. Experiments were conducted in greenhouse trials using three naturally infested field soils and a susceptible variety of sweet bell pepper (Capsicum annuum).

\section{Materials and Methods}

Soils. Greenhouse trials were conducted using soil collected from three farms with recent outbreaks of phytophthora blight. All 
soils were collected from areas below infested fruit at a sampling depth of $0-10 \mathrm{~cm}$. One of the soils (Wawaka) was collected in Spring 2012 from a field with Wawaka loam soil (fine loamy, mixed, active, medic Typic Hapludalfs), in Middletown, IN (lat. $40.08^{\circ}$ and long. $-85.50^{\circ}$ ) where pumpkin was grown the previous season. The other two were collected in Autumn 2012 from farms near Vincennes, IN. One of these fields (Ayrshire and Conotton) (lat. $38.47^{\circ}$ and long. $-87.63^{\circ}$ ) contained a poorly drained Ayrshire (fine loamy, mixed, active, mesic Aeric Endoaqualfs) and Conotton (loamy skeletal, mixed, active, mesic Typic Hapludalfs) clay loam soil, planted with watermelon during the previous summer growing season. The second field in Vincennes, IN (Ayshire and Zipp) (lat. 38.48 and long. $\left.-87.61^{\circ}\right)$ contained a poorly drained Ayrshire (fine loamy, mixed, active, mesic Aeric Endoaqualfs) and Zipp (fine, mixed, active, nonacid, mesic Typic Endoaquepts) loam soil, planted with pumpkin during the previous growing season. Initial chemical properties for each soil were determined at Midwest Laboratories (Omaha, NE), and are listed in Table 1. After collection from the field, soils were stored at $4{ }^{\circ} \mathrm{C}$ to limit biological activity until greenhouse experiments were conducted.

Amendments. We tested two commercially available biochar amendments. One biochar amendment (B1) (Diacarbon Energy
Inc., Burnaby, BC, Canada) was produced from a softwood parent material that was pyrolyzed for $1 \mathrm{~h}$ at temperatures between 450 and $550{ }^{\circ} \mathrm{C}$, and ground and sieved to create particle sizes of $4 \mathrm{~mm}$. The other biochar amendment (B2) (Charcoal Green, Crawford, NE) was produced from a softwood parent material that was pyrolyzed for $1 \mathrm{~h}$ at temperatures between 550 and $600{ }^{\circ} \mathrm{C}$, amended with a proprietary mix of beneficial soil microorganisms and enriched substrates, and ground and formed into pellets for application purposes. Properties of the biochar amendments were determined by Midwest Laboratories and are listed in Table 2. Biochar (B1) contained more total carbon (C) and iron, and had a greater $\mathrm{C}$ to nitrogen $(\mathrm{N})$ ratio and $\mathrm{pH}$ than $\mathrm{B} 2$, whereas $\mathrm{B} 2$ contained more ash, and had a greater concentration of macronutrients and other micronutrients.

Plant material. Seeds of a susceptible bell pepper variety, 'California Wonder', were obtained from Sustainable Seed Company (Covelo, CA). Before planting, seeds were surface sterilized in a $25 \%$ sodium hypochlorite solution containing $0.01 \%$ Tween-20 (Sigma, St. Louis, MO). Seeds were planted in 72-cell trays containing Fafard Super-Fine Germinating Mix (Conrad Fafard Inc., Agawam, MA) and subject to $4 \mathrm{~s}$ of mist every $20 \mathrm{~m}$, and a mean temperature of $23{ }^{\circ} \mathrm{C}$ to facilitate germination. After $14 \mathrm{~d}$, trays were thinned to one plant per cell and transferred to the greenhouse where they were watered alternately with clear water and fertilizer water every other day for 6 weeks. The fertilizer water contained a combination of two water-soluble fertilizers $(3: 1$ mixture of $15 \mathrm{~N}-2.2 \mathrm{P}-12.5 \mathrm{~K}$ and $21 \mathrm{~N}-2.2 \mathrm{P}-16.6 \mathrm{~K}$, respectively (The Scotts Co., Marysville, $\mathrm{OH}$ ). All irrigation water was supplemented with 93\% sulfuric acid (Brenntag, Reading, PA) at $0.08 \mathrm{~mL} / \mathrm{L}$ to reduce alkalinity to $100 \mathrm{mg} \cdot \mathrm{L}^{-1}$ and $\mathrm{pH}$ to a range of 5.8-6.2.

Experimental design. Soil from each location was mixed and sieved $(4 \mathrm{~mm})$ to remove rocks and plant debris, distributed in $10-\mathrm{cm}$ pots $(0.5 \mathrm{~L})$, and subject to the following treatments: 1) untreated control, 2) soil pasteurization, 3) biochar (B1), and 4) biochar (B2), with five replicates per treatment. Each biochar amendment was applied at a rate of $3 \%(\mathrm{w} / \mathrm{w})$, based on previous reports of disease suppression at this rate (Elad et al., 2010; Meller Harel et al., 2012). Pots were arranged in a randomized complete block design, and each pot was contained in a $20-\mathrm{cm}$ circular tray and subirrigated with clear water to keep soil moist and provide conditions conducive for phytophthora blight. The greenhouse was maintained at a mean temperature of $24^{\circ} \mathrm{C}$ with a 16 -h photoperiod. Two weeks after soil treatment, 8-week-old pepper seedlings were transplanted into each pot,

Table 1. Chemical properties of three soils naturally infested with Phytophthora capsici before soil amendment in greenhouse trials.

\begin{tabular}{|c|c|c|c|c|c|c|c|c|c|c|c|}
\hline \multirow[b]{2}{*}{ Soil } & \multirow[b]{2}{*}{$\mathrm{pH}$} & \multirow[b]{2}{*}{$\%$ Organic matter } & \multirow{2}{*}{$\begin{array}{c}\text { Cation } \\
\text { exchange capacity }\end{array}$} & \multicolumn{4}{|c|}{ ppm } & \multicolumn{4}{|c|}{$\%$ Base saturation } \\
\hline & & & & $\mathrm{P}$ & $\mathrm{K}$ & $\mathrm{Mg}$ & $\mathrm{Ca}$ & $\mathrm{K}$ & $\mathrm{Mg}$ & $\mathrm{Ca}$ & $\mathrm{H}$ \\
\hline Wawaka & 6.0 & 2.4 & 13.3 & 34 & 171 & 215 & 1,804 & 3.3 & 13.25 & 67.8 & $\overline{15.4}$ \\
\hline Ayrshire and Conotton & 6.6 & 2.1 & 18.1 & 44 & 273 & 286 & 2,791 & 3.9 & 13.2 & 77.1 & 5.8 \\
\hline Ayrshire and Zipp & 7.3 & 2.0 & 13.3 & 39 & 258 & 120 & 2,330 & 5.0 & 7.5 & 87.5 & 0 \\
\hline
\end{tabular}

Table 2. Chemical properties of two commercially available biochar amendments used in greenhouse trials.

\begin{tabular}{|c|c|c|c|c|c|c|}
\hline & \multicolumn{3}{|c|}{ Biochar (B1) } & \multicolumn{3}{|c|}{ Biochar (B2) } \\
\hline & Wet basis & Dry basis & Total content (lbs/ton) & Wet basis & Dry basis & Total content (lbs/ton) \\
\hline Moisture (\%) & 5.8 & - & - & 15.2 & - & - \\
\hline Total solids (\%) & 94.2 & - & 1,884 & 84.8 & - & 1,696 \\
\hline Organic matter & 90.8 & 96.4 & 1,816 & 67.4 & 79.5 & 1,348 \\
\hline Ash & 3.3 & 3.5 & 66.0 & 17.3 & 20.4 & 346 \\
\hline Total carbon (\%) & 76.8 & 81.5 & - & 47.7 & 56.3 & - \\
\hline $\mathrm{C}: \mathrm{N}$ ratio & $183: 1$ & - & - & $29: 1$ & - & - \\
\hline Chloride (\%) & 0.02 & 0.02 & - & 0.28 & 0.33 & - \\
\hline $\mathrm{pH}$ & 7.9 & - & - & 6.5 & - & - \\
\hline \multicolumn{7}{|l|}{ Nitrogen } \\
\hline Total N (\%) & 0.42 & 0.45 & 8.4 & 1.67 & 1.97 & 33.4 \\
\hline Organic N (\%) & 0.42 & 0.45 & 8.4 & 1.51 & 1.78 & 30.10 \\
\hline Ammonium nitrogen $(\%)$ & $<0.001$ & - & - & 0.114 & 0.134 & 2.300 \\
\hline Nitrate nitrogen $(\%)$ & $<0.01$ & - & - & 0.05 & 0.06 & 1.00 \\
\hline \multicolumn{7}{|l|}{ Major and secondary nutrients } \\
\hline Phosphorus (\%) & $<0.05$ & - & - & 0.21 & 0.25 & 4.2 \\
\hline Phosphorus as $\mathrm{P}_{2} \mathrm{O}_{5}(\%)$ & $<0.10$ & - & - & 0.48 & 0.57 & 9.6 \\
\hline Potassium (\%) & 0.17 & 0.18 & 3.4 & 0.71 & 0.84 & 14.2 \\
\hline Potassium as $\mathrm{K}_{2} \mathrm{O}(\%)$ & 0.20 & 0.21 & 4.0 & 0.86 & 1.01 & 17.2 \\
\hline Sulfur $(\%)$ & $<0.05$ & - & - & 0.40 & 0.47 & 8.00 \\
\hline Calcium (\%) & 0.68 & 0.72 & 13.6 & 1.74 & 2.05 & 34.8 \\
\hline Magnesium (\%) & 0.22 & 0.23 & 4.4 & 0.23 & 0.27 & 4.6 \\
\hline Sodium (\%) & 0.140 & 0.149 & 2.8 & 0.220 & 0.259 & 4.4 \\
\hline \multicolumn{7}{|l|}{ Micronutrients } \\
\hline Zinc (ppm) & 87.7 & 93 & 0.2 & 124 & 146 & 0.2 \\
\hline Iron (ppm) & 4,350 & 4,618 & 8.7 & 1,590 & 1,875 & 3.2 \\
\hline Manganese (ppm) & 211 & 224 & 0.4 & 236 & 278 & 0.5 \\
\hline Copper (ppm) & $<20$ & - & - & 98.4 & 116 & 0.2 \\
\hline Boron (ppm) & $<20$ & - & - & $<20$ & - & - \\
\hline
\end{tabular}


amended with $3 \mathrm{~g} \cdot \mathrm{L}^{-1}$ Osmocote $19 \mathrm{~N}-6 \mathrm{P}-12 \mathrm{~K}$ (The Scotts Co., Marysville, $\mathrm{OH}$ ), and irrigated for $\approx 5 \mathrm{~s}$ to help dissolve the fertilizer.

Plant productivity assays. Plants were harvested $14 \mathrm{~d}$ after transplanting into pots. Relative chlorophyll content of pepper leaves was measured just before harvest with a SPAD-502 m (Minolta Corporation, Ramsey, NJ). Measurements were made on three randomly selected mature leaves per plant, with two readings per leaf. Roots were rinsed under tap water to remove all adhering soil, and root and shoot length were determined. Individual plant root subsamples (wet weight, $5 \mathrm{~g}$ ) were collected using aseptic techniques and stored at $4{ }^{\circ} \mathrm{C}$ until determination of root system infection. Remaining plant biomass was separated into above and belowground categories, weighed, and ovendried at $60{ }^{\circ} \mathrm{C}$ for $48 \mathrm{~h}$ before weighing again to determine dry weight. About $75 \mathrm{~g}$ of soil remaining in each pot was collected and stored at $4{ }^{\circ} \mathrm{C}$ until laboratory analysis. Root infection by $P$. capsici was estimated using 10 root cuttings $(3-5 \mathrm{~mm})$ plated on a medium semiselective for Phytophthora and Pythium species (PSSM) (Mazzola et al., 2001), and the percentage of root cuttings that exhibited mycelial growth was quantified $48 \mathrm{~h}$ after plating.

Soil assays. Before laboratory analysis, soil samples were thawed, dried, ground, and sieved to $2 \mathrm{~mm}$ for all assays except plate counts in which field moist soil was used. To determine plant available nitrogen, soil extracts were created by mixing $5 \mathrm{~g}$ of dry weight soil in $12.5 \mathrm{~mL}$ of $1.0 \mathrm{~mol} \cdot \mathrm{L}^{-1} \mathrm{KCl}$, shaken for $30 \mathrm{~m}$ at $350 \mathrm{rpm}$, filtered with qualitative filter paper 2 (Dot Scientific Inc., Burton, MI), and spectrophotometrically analyzed for ammonium- $\left(\mathrm{NH}_{4}{ }^{+}-\mathrm{N}\right)$ and nitrate/ nitrite- $\left(\mathrm{NO}_{\mathrm{x}}-\mathrm{N}\right) \mathrm{N}$ concentration using a SEAL AQ2 (SEAL Analytical Inc., Mequon,
WI). Concentrations of $\mathrm{NH}_{4}{ }^{+}-\mathrm{N}$ and $\mathrm{NO}_{\mathrm{x}}-\mathrm{N}$ were combined and expressed as mineral $\mathrm{N}$. Soil microbial activity was estimated using the hydrolysis of fluorescein diacetate [3', $6^{\prime}$-diacetylfluorescein (FDA)] on soil slurries using a method described in Green and Stott (2006). Reacted samples and standards were measured at $490 \mathrm{~nm}$ on a BioTek Epoch plate reader (BioTek, Winooski, VT). Soil $P$. capsici abundance was estimated by counting colony-forming units following serial dilutions plated on PSSM. Soil $(\mathrm{pH})$ was determined following a protocol outlined in Conyers and Davey (1988), using a 1:2 soilto-deionized water ratio. Measurements were taken using a sensION + mm150 multimeter (Hach Company, Loveland, CO).

Statistical analysis. Data were analyzed using standard analyses of variance procedures in SAS (SAS version 9.2; SAS Institute Inc., Cary, NC) using PROC GLM, and means separated using Tukey's honestly significant difference test $(P<0.05)$. Data were checked for model assumptions, and square root or log transformed when normality or equality of variance were not met. Data were back-transformed to report means in tables and figures. Data are reported separately by soil because of significant soil-bytreatment interactions, with the exception of root and shoot length, SPAD reading, and mineral $\mathrm{N}$ where the interaction of these factors was not significant. Relationships between plant and soil parameters were evaluated with Spearman's rank correlation analyses using PROC CORR.

\section{Results}

Plant biomass. Both soil and treatment significantly affected root length (Table 3 ).
When compared across treatments, root length was greatest in the Ayrshire and Conotton soil, followed by Aryshire and Zipp, and lowest in the Wawaka soil. When compared across soils, root length was lower in the pasteurized treatment relative to the control. Shoot length was also influenced by soil type with the greatest length in the Ayrshire and Conotton soil, intermediate in the Ayrshire and Zipp, and lowest in the Wawaka (Table 2). In contrast, there was no effect of treatment on shoot length across the three soils tested (Table 3). Soil pasteurization reduced root dry weight relative to the other treatments in the Wawaka soil, increased root dry weight relative to the other treatments in the Aryshire and Conotton soil, and increased root dry weight relative to the control and B2 treatment in the Ayrshire and Zipp soil (Table 4). There were no significant differences in shoot dry weight among treatments in any of the three soils tested (Table 4).

Soil and plant chemical analyses. Mineral $\mathrm{N}$ was not different among soils when compared across treatments, but was lower in the B2 treatment relative to the control when compared across the three soils tested (Table 3). Relative leaf chlorophyll content estimated by a SPAD meter was also not different among soils when compared across treatments, but was lower in the B2 treatment relative to the other treatments when compared across the three soils tested (Table 3 ). Soil $\mathrm{pH}$ was greater in the pasteurized and B2 treatments relative to the control in both the Wawaka and Aryshire and Conotton soils, but was unaffected by soil treatment in the Aryshire and Zipp soil (Fig. 1). No significant correlations were detected between plant and soil chemical parameters (data not shown).

Table 3. Mean root and shoot length of sweet pepper (Capsicum annuum), soil mineral N, and SPAD reading collected after treatment of three soils naturally infested with Phytophthora capsici in greenhouse trials.

\begin{tabular}{|c|c|c|c|c|c|}
\hline & & Root length $(\mathrm{cm})$ & Shoot length $(\mathrm{cm})$ & Soil mineral N (ug.g ${ }^{-1}$ ) & SPAD reading \\
\hline \multicolumn{6}{|l|}{ Field } \\
\hline Ayrshire and Conotton & & $19.6(0.6) \mathrm{a}$ & $27.3(1.9) \mathrm{a}$ & $1,949.1(188.8) \mathrm{a}$ & $64.3(1.2) \mathrm{a}$ \\
\hline Ayrshire and Zipp & & $15.5(1.0) \mathrm{b}$ & $23.5(1.8) b$ & $2,189.9(166.2)$ a & $60.6(1.3) \mathrm{a}$ \\
\hline Control & & $16.1(1.7) \mathrm{a}$ & $23.6(2.3) \mathrm{a}$ & $2,537.7(144.9) \mathrm{a}$ & $63.7(1.5) \mathrm{a}$ \\
\hline Pasteurized & & $13.1(1.9) \mathrm{b}$ & $24.2(1.6) \mathrm{a}$ & $2,037.4(126.3) \mathrm{ab}$ & $66.1(0.3) \mathrm{a}$ \\
\hline Biochar (B1) & & $16.6(1.6) \mathrm{a}$ & $25.2(1.5) \mathrm{a}$ & $2,067.7(149.4) a b$ & $63.9(0.2) \mathrm{a}$ \\
\hline Field (F) & 2 & $<0.0001$ & $<0.0001$ & 0.4351 & 0.0522 \\
\hline Treatment $(\mathrm{T})$ & 3 & 0.0045 & 0.3023 & 0.0507 & 0.0011 \\
\hline $\mathrm{F} \times \mathrm{T}$ & 7 & 0.7411 & 0.0609 & 0.3232 & 0.5466 \\
\hline
\end{tabular}

$\mathrm{df}=$ degrees of freedom.

${ }^{\mathrm{z}}$ Values in parentheses are $1 \mathrm{SE}$.

${ }^{\mathrm{y}}$ Different letters within a column represent significant difference as determined by Tukey's honestly significant difference test $(P<0.05)$.

Table 4. Root and shoot dry weight of sweet pepper following treatment of three soils naturally infested with Phytophthora capsici in greenhouse trials.

\begin{tabular}{|c|c|c|c|c|c|c|}
\hline \multirow[b]{2}{*}{ Treatment } & \multicolumn{2}{|c|}{ Wawaka } & \multicolumn{2}{|c|}{ Aryshire and Conotton } & \multicolumn{2}{|c|}{ Aryshire and Zipp } \\
\hline & Root wt (g) & Shoot wt $(\mathrm{g})$ & Root wt (g) & Shoot wt (g) & Root wt (g) & Shoot wt $(\mathrm{g})$ \\
\hline Pastuerized & $0.26(0.13) \mathrm{b}$ & $4.52(1.16) \mathrm{a}$ & $1.80(0.20) \mathrm{a}$ & $4.20(0.20) \mathrm{a}$ & $2.90(0.51) \mathrm{a}$ & $5.80(0.38)$ a \\
\hline Biochar (B2) & $1.12(0.17) \mathrm{a}$ & $5.24(0.31) \mathrm{a}$ & $1.20(0.20) \mathrm{b}$ & $3.20(0.66) \mathrm{a}$ & $1.06(0.28) b$ & $4.16(0.76) \mathrm{a}$ \\
\hline
\end{tabular}

${ }^{2}$ Values in parentheses are $1 \mathrm{SE}$.

${ }^{y}$ Different letters within a column represent significant difference as determined by Tukey's honestly significant difference test $(P<0.05)$. 


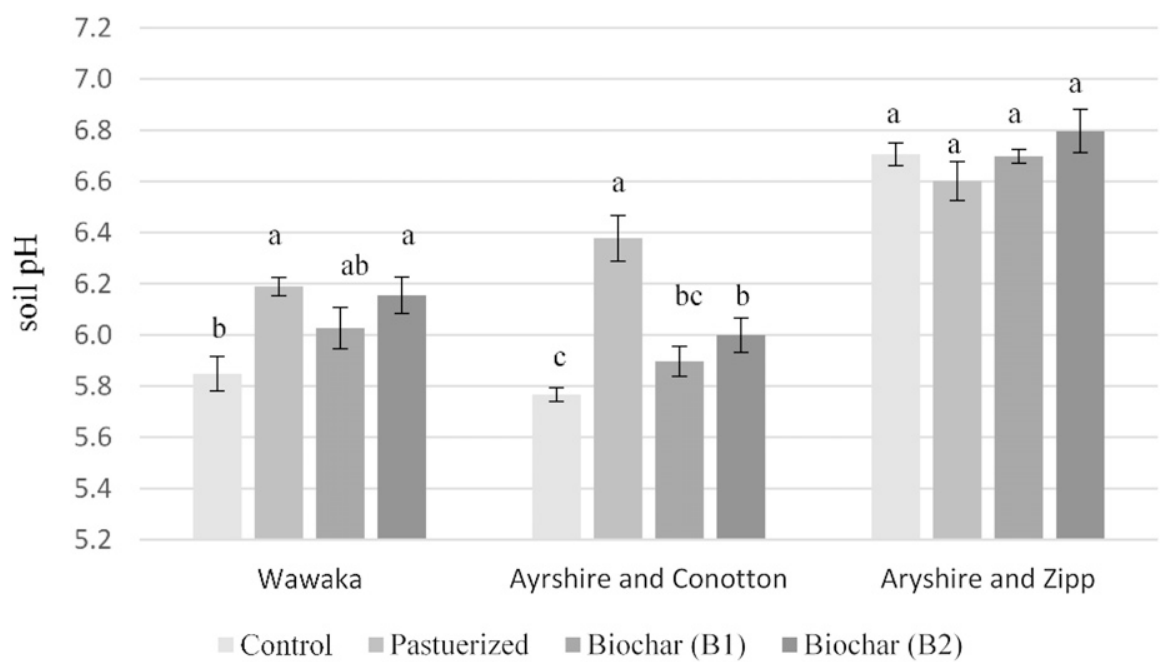

Fig. 1. Soil $\mathrm{pH}$ following treatment of three soils naturally infested with Phytophthora capsici in greenhouse trials. Within a soil, values represented by bars designated with the same letter are not significantly different $(P>0.05)$.

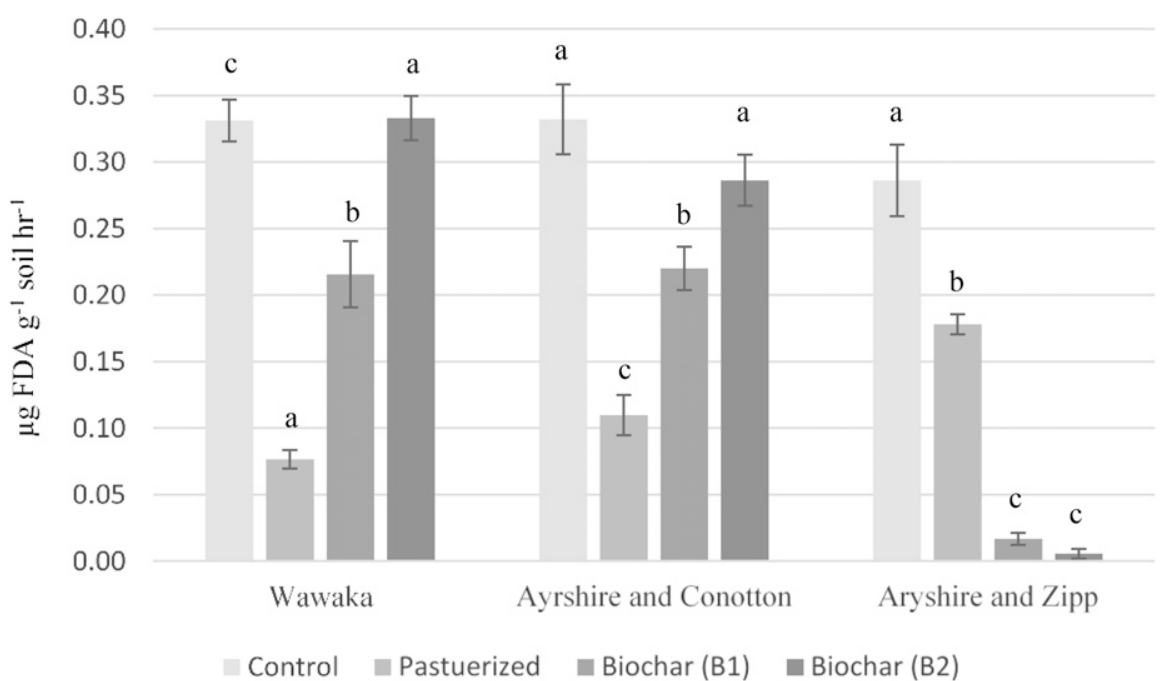

Fig. 2. Soil microbial activity [fluorescein diacetate (FDA)] following amendment of three soils naturally infested with Phytophthora capsici in greenhouse trials. Within a soil, values represented by bars designated with the same letter are not significantly different $(P>0.05)$.

Soil and plant microbial analyses. Soil microbial activity estimated by FDA hydrolysis was significantly impacted by biochar amendments in each of the three soils tested (Fig. 2). Soil pasteurization resulted in lower microbial activity than the control in all soils, and microbial activity was lower in the pasteurized treatment relative to both biochar amendments in the Wawaka and Aryshire and Conotton soils, but not in the Aryshire and Zipp soil. Microbial activity was also lower in the $\mathrm{B} 1$ treatment relative to the control in all soils, and lower in the B2 treatment relative to the control in the Aryshire and Zipp soil. Phytophthora capsici soil abundance was lower in the pasteurized treatment relative to the control in all soils, and lower in the B2 treatment relative to the control in the Aryshire and Conotton and Aryshire and Zipp soils (Fig. 3). Percent root infection by $P$. capsici was lower in the B2 response to biochar amendments (Atucha and Litus, 2015; Elmer and Pignatello, 2011; Jaiswal et al., 2014; Matsubara et al., 2002; Nerome et al., 2005; Zwart and Kim, 2012). However, like Jaiswal et al. (2014), our results indicate that suppressive effects depend on the type of biochar amendment applied, as well as soil type. Biochar is well known for its potential to alter soil physical, chemical, and biological properties, and such changes are theorized to directly and/or indirectly contribute to its suppressive activity (Graber et al., 2015). Feedstock, pyrolysis conditions, and inoculation with beneficial microbes are all factors which have the potential to alter the effect of biochar amendments on soil properties. Both amendments tested in this study were made from softwood parent materials, but they were produced by different companies and likely contained different types of plant species. The amendments were also produced at different hydrolysis temperatures, and one was inoculated with a proprietary mix of beneficial microorganisms and other substrates. Consequently, we cannot determine which factor(s) contributed to the suppressive activity observed in this study, and recommend additional studies that focus on each of these factors alone and in combination, to determine which are most important for suppression of phytophthora blight.

Greater understanding of the mechanisms regulating biochar-mediated suppression is needed to develop products that can consistently reduce soil-borne diseases in the field. Biocontrol activity, whereby beneficial soil microorganisms outcompete or directly inhibit pathogens by stimulating plant growth, producing antibiotic compounds, and/or inducing systemic resistance, is often cited as one potential mechanism for the suppressive effect of biochar amendments (Elad et al., 2011; Graber et al., 2010; Kolton et al., 2011). Many of these so-called plant growthpromoting rhizobacteria (PGPR) and fungi (PGPF) have been demonstrated to control soil-borne pathogens, including $P$. capsici, under controlled conditions (Siddiqui, 2006; Zhang et al., 2010). However, direct application of microbial strains formulated for commercial use often fail to persist long enough to suppress disease in field trials, likely because these strains must compete with resident microbial species (Cook, 2007). Many studies have observed greater soil microbial activity in response to biochar amendments (Lehmann et al., 2011), and greater populations of PGPR(F), including Pseudomonas, Bacillus, and Trichoderma species, have been observed in biochar-amended potting mix (Elad et al., 2010). The presence of these microbial sp. was correlated with resistance to two foliar pathogens (Botrytis cinerea and Leveillula taurica) in pepper and tomato (Elad et al., 2010), and upregulation of select genes commonly associated with induced systemic resistance (Mehari et al., 2015; Meller Harel et al., 2012). Because of its stability, microbes likely receive little carbon from biochar amendments, but its large internal surface area 
a

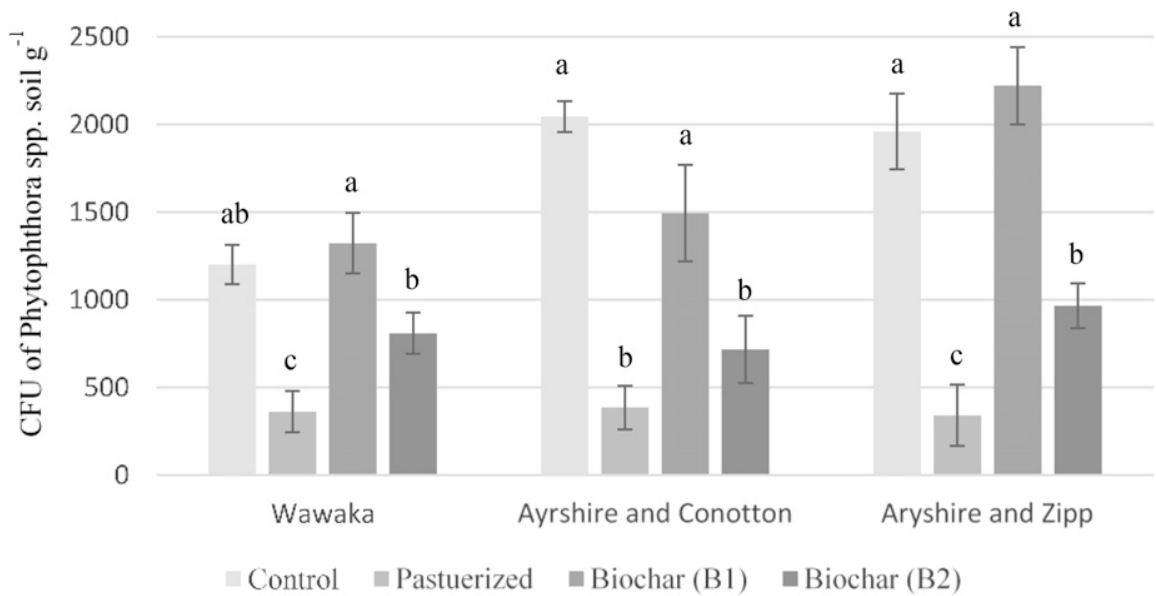

Fig. 3. Populations of Phytophthora capsici following amendment of three soils naturally infested with $P$. capsici in greenhouse trials. Within a soil, values represented by bars designated with the same letter are not significantly different $(P>0.05)$.

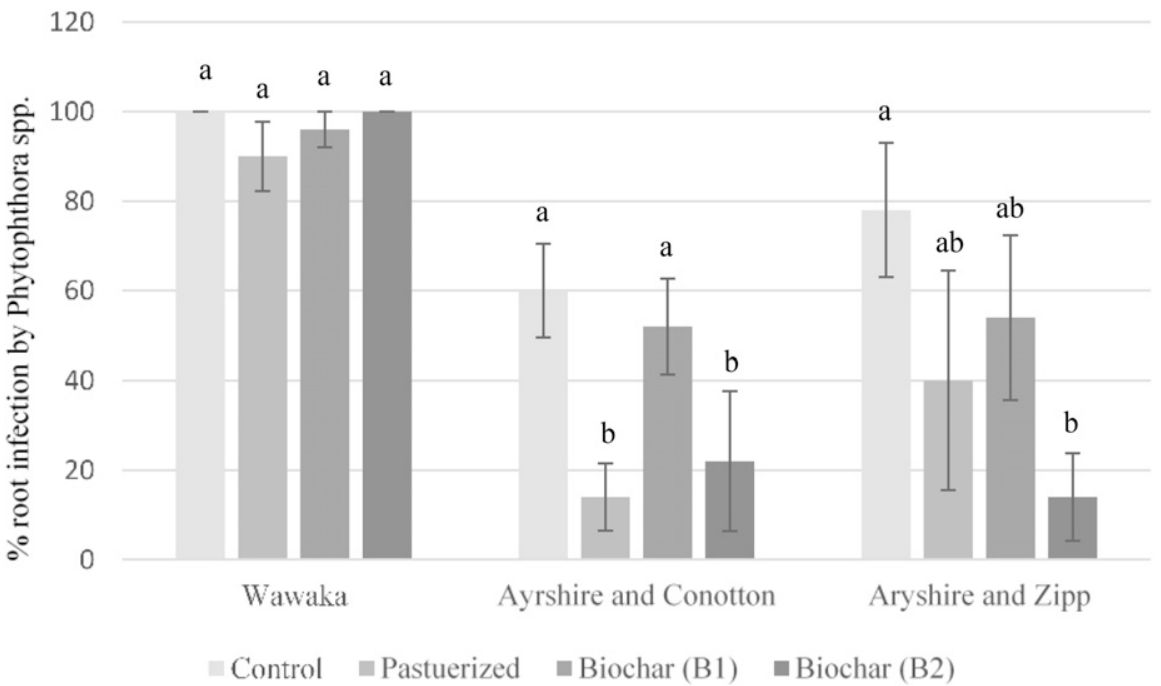

Fig. 4. Percent root infection by Phytophthora capsici in pepper following treatment and growth in three soils naturally infested with Phytophthora capsici in greenhouse trials. Within a soil, values represented by bars designated with the same letter are not significantly different $(P>0.05)$.

could provide an ideal habitat for soil microbes. Consequently, biochar has been suggested as an ideal carrier for microbial strains developed for use as inoculants (Thies and Rillig, 2009), and many commercially available biochar products are amended with these microorganisms.

Surprisingly, we observed lower soil microbial activity in response to B1 in all soils, and either no change or reduced activity in response to $\mathrm{B} 2$ which had been amended with a proprietary mix of beneficial microorganisms. This contradicts results of many studies which have observed greater microbial activity in response to biochar amendments (Lehmann et al., 2011), and does not support the hypothesis that PGPR $(\mathrm{F})$ played a role in the suppressive effects observed in this study. However, lower microbial activity in response to biochar amendments could have been related to sorption of substrates used in
Changes in soil physical properties is another factor that could contribute to the suppressive effects of biochar amendments. For example, many studies have observed changes in soil physical properties including lower bulk density (Downie et al., 2009; Laird et al., 2010; Lehmann et al., 2006) and greater soil tilth (Glaser et al., 2002) following biochar amendment. Compacted soils restrict root growth and prevent drainage, which provide ideal conditions for damage by many soil-borne pathogens. However, biochar amendment can also increase soil water holding capacity (Downie et al., 2009; Laird et al., 2010), which could exacerbate damage by oomycete pathogens like $P$. capsici. In the present study, soils were intentionally kept overly moist to create conditions conducive to $P$. capsici development and thus any potential changes in soil physical properties, which could have influenced soil moisture, were likely obscured. Consequently, any potential changes in soil physical properties resulting from biochar amendment were not likely related to the suppressive effects observed in this study. In addition, our results indicate that any potential increases in soil water holding capacity that could be induced by biochar amendments are not likely to exacerbate phythophthora blight.

The suppressive effects observed in this study may have been related to changes in soil chemical properties. Many studies have observed changes in soil $\mathrm{pH}$, cation exchange capacity, and nutrient retention and availability in response to biochar amendments (Clough et al., 2013; Laird et al., 2010; Liang et al., 2006; Singh et al., 2010; Spokas et al., 2011; Ventura et al., 2013). Soil pH influences the solubility and availability of trace elements, and it is a key driver of soil microbial composition and activity (Kammann and Graber, 2015; Lehmann et al., 2011). Many soil-borne pathogens thrive under relatively narrow pH ranges (Husson, 2012), and changes in soil $\mathrm{pH}$ have been suggested as one potential factor that could influence biochar's suppressive activity (Elad et al., 2011; Graber et al., 2015). Consistent with other studies (Laird et al., 2010; Novak et al., 2009; Van Zwieten et al., 2010), B2 increased soil $\mathrm{pH}$ in two of the three soils tested. Interestingly, $\mathrm{B} 1$ did not increase soil $\mathrm{pH}$ even though it had a much greater $\mathrm{pH}$ than $\mathrm{B}$ 2, indicating that changes in $\mathrm{pH}$ were more likely related to additions of calcium $(\mathrm{Ca})$ from $\mathrm{B} 2$, than the $\mathrm{pH}$ of the amendment itself. Nevertheless, changes in $\mathrm{pH}$ do not appear to be directly related to suppressive effects observed this study, as corresponding reductions in pathogen abundance and root infection were only observed in one soil. In addition, previous studies testing effects of soil $\mathrm{pH}$ on phytophthora blight indicate that disease severity is greater when soil $\mathrm{pH}$ is increased, which could be related to lower amounts of exchangeable aluminum (Al) which has the potential to be toxic to P. capsici (Muchovej et al., 1980).

Nutrient availability is a key driver regulating pathogen dynamics and plant health, 
which can be influenced by biochar amendments, and could have contributed to the suppressive effects observed in this study. Many studies have observed greater cation exchange capacity in response to biochar amendments resulting in greater plant available nutrients in the root zone (Glaser et al., 2002; Laird, 2008). Greater access to nutrients has been shown to decrease root hair development (Prendergast-Miller et al., 2014), thereby reducing surface area for infection by soil-borne pathogens (Graber et al., 2015). Nutrient availability was not meant to be limiting in this study and all pots received sufficient nutrients to support young pepper growth. Nevertheless, the biochar with suppressive potential, B2, contained considerable amounts of $\mathrm{P}, \mathrm{K}$, and $\mathrm{Ca}$, as well as a limited amount of $\mathrm{Mg}$ which could have contributed to the suppressive effects observed. Each of these nutrients has previously been demonstrated to reduce diseases caused by soil-borne pathogens. For example, $P$. capsici infection was reduced by phosphate additions (Förster et al., 1998), and $\mathrm{Ca}$ and $\mathrm{Mg}$ reduced infection by Pythium (Kao and Ko, 1986; Lumsden et al., 1987) and Fusarium species (Höper et al., 1995). Several studies have observed greater foliar concentrations of $\mathrm{Mg}$ in response to biochar amendments (Atucha and Litus, 2015; Elmer and Pignatello, 2011; Major et al., 2010; Wang et al., 2014), and Atucha and Litus (2015) theorized that this could have contributed to reduced severity of peach replant disease observed in their study.

Many studies have observed changes in $\mathrm{N}$ dynamics in response to biochar amendments, with greater soil retention and availability in some studies (Atucha and Litus, 2015; Lehmann et al., 2003; Spokas et al., 2011; Ventura et al., 2013), and lower availability as a result of potential immobilization in others (Ameloot et al., 2015; Bruun et al., 2012; Clough et al., 2013). Surprisingly, B1, which had a very high $\mathrm{C}: \mathrm{N}$ ratio, did not appear to affect soil or leaf $\mathrm{N}$ content, whereas B2, which had a much lower C:N ratio and greater $\mathrm{N}$ contribution, resulted in lower soil $\mathrm{N}$ availability and leaf chlorophyll content. Reduced N availability and uptake could have contributed to lower pathogen infection. Abundant soil $\mathrm{N}$ can increase vegetative growth and make plants more attractive to some pests. Greater soil N availability has previously been reported to increase damage by Pythium sp. and Rhizoctonia solani (Baker and Martinson, 1970; Wall et al., 1994).

Surprisingly, we did not observe stimulation of root or shoot biomass in response to either biochar amendment, which contradicts results of other studies (Laird et al., 2010; Lehmann et al., 2011; Watts et al., 2005). Lack of a plant growth response could be related to the amount of biochar that was applied in this study, as rates of biochar that have shown an effect on disease suppression differ from those that most stimulate plant productivity (Jaiswal et al., 2014). Some biochar amendments contain residual tars that include organic compounds such as ethylene (Anderson et al., 2013), which can enhance or reduce plant productivity depending on the concentration. It has been suggested that these compounds could be responsible for the U-shaped biochar dose response curve observed in many studies with soil-borne pathogens (Elad et al., 2011; Jaiswal et al., 2014; Matsubara et al., 2002; Nerome et al., 2005; Zwart and Kim, 2012). When found in low concentrations, these compounds aid in seed germination, enhance growth of beneficial microorganisms, and exhibit biocidal properties (Amonette and Joseph, 2009; Elad et al., 2010; Schnitzer et al., 2008), whereas at higher concentrations they negatively impact root growth and make plants more susceptible to pathogen attack (Ye et al., 2004). Alternatively, our experiments may not have been conducted long enough to observe beneficial effects of biochar on plant productivity.

\section{Conclusions}

Results of this study indicate that some commercially available biochar amendments have the potential to help suppress phytophthora blight, but further trials are needed to confirm that suppressive effects will also be observed in field trials. Additional research is also needed to identify the mechanisms regulating biochar-mediated suppressive effects to develop products that can reliably suppress diseases in the field. Currently, limited availability of commercial sources of biochar amendments, high costs, and variability in physical and chemical properties limit the practical deployment of biochar as an effective disease suppressive strategy. Growers will also need to consider confounding effects such as potential contaminants and human health risks of some biochar amendments (Montanarella and Lugato, 2013) as well as biochar's potential to sorb and reduce pesticidal activity (Cabrera et al., 2014; Jones et al., 2011) before deciding whether to include biochar in their portfolio against soil-borne pathogens like $P$. capsici. Nevertheless, as more studies demonstrate the potential for biochar to suppress soil-borne pathogens, the mechanisms regulating biochar-mediated pathogen suppression are determined, and alternative energy sources continue to become more attractive. Therefore, biochar has great potential to become a valuable tool in the fight against soil-borne pathogens.

\section{Literature Cited}

Ameloot, N., S. Sleutel, K.C. Das, J. Kanagratnam, and S. De Neve. 2015. Biochar amendment to soils with contrasting organic matter level: Effects on $\mathrm{N}$ mineralization and biological soil properties. GCB Bioenergy 7:135-144.

Amonette, J.E. and S. Joseph. 2009. Characteristics of biochar: Microchemical properties, p. 33-52. In: J. Lehmann and S. Joseph (eds.). Biochar for environmental management. Earthscan, London, UK.

Anderson, N., J.G. Jones, D. Page-Dumrose, D. McCollum, S. Baker, D. Loeffler, and W. Chung. 2013. A comparison of producer gas, biochar, and activated carbon from two distributed scale thermochemical conversion systems used to process forest biomass. Energies 6:164183.

Atucha, A. and G. Litus. 2015. Effect of biochar amendments on peach replant disease. HortScience 50:863-868.

Babadoost, M. and T.A. Zitter. 2009. Fruit rots of pumpkin: A serious threat to the pumpkin industry. Plant Dis. 93:772-782.

Bailey, V.L., S.J. Fansler, J.L. Smith, and H. Bolton, Jr. 2011. Reconciling apparent variability in effects of 11 biochar amendment on soil enzyme activities by assay optimization. Soil Biol. Biochem. 43:296-301.

Baker, R. and C.A. Martinson. 1970. Epidemiology of diseases caused by Rhizoctonia solani, $\mathrm{p}$. 125-148. In: J.R. Parmeter (ed.). Biology and pathology. University of California Press, Berkeley, CA.

Bruun, E.W., P. Ambus, H. Egsgaard, and H. Hauggaard-Nielsen. 2012. Effects of slow and fast pyrolysis biochar on soil $\mathrm{C}$ and $\mathrm{N}$ turnover dynamics. Soil Biol. Biochem. 46:73-79.

Cabrera, A., L. Cox, K. Spokas, M.C. Hermosín, J. Cornejo, and W.C. Koskinen. 2014. Influence of biochar amendments on the sorptiondesorption of aminocyclopyrachlor, bentazone and pyraclostrobin pesticides to an agricultural soil. Sci. Total Environ. 470:438-443.

Cook, R.J. 2007. Management of resident plant growth-promoting rhizobacterial with the cropping system: A review of experience in the US Pacific Northwest. Eur. J. Plant Pathol. 119: 255-264.

Clough, T.J., L.M. Condron, C. Kammann, and C. Moeller. 2013. A review of biochar and soil nitrogen dynamics. Agronomy 3:275-293.

Conyers, M.K. and B.G. Davey. 1988. Observations on some routine methods for soil $\mathrm{pH}$ determination. Soil Sci. 145:29-36.

Downie, A., A. Crosky, and P. Munroe. 2009. Physical properties of biochar, p. 13-32. In: J. Lehmann and S. Joseph (eds.). Biochar for environmental management. Earthscan, London, UK.

Elad, Y., D.R. David, Y.M. Harel, M. Borenshtein, H.B. Kalifa, A. Silber, and E.R. Graber. 2010. Induction of systemic resistance in plants by biochar, a soil-applied carbon sequestering agent. Phytopathology 100:913-921.

Elad, Y., E. Cytryn, Y.M. Harel, B. Lew, and E.R. Graber. 2011. The biochar effect: Plant resistance to biotic stresses. Phytopathol. Mediterr. 50:335-349.

Elmer, W.H. and J.J. Pignatello. 2011. Effect if biochar amendments on mycorrhizal and fusarium crown and root rot of asparagus in replant soils. Plant Dis. 95:960-966.

Erwin, D.C. and O.K. Ribeiro. 1996. Phytophthora diseases worldwide. Amer. Phytopathol. Soc., St. Paul, MN

Förster, H., J.E. Adaskaveg, D.H. Kim, and M.E. Stanghellini. 1998. Effect of phosphite on tomato and pepper plants and on susceptibility of pepper to phytophthora root and crown rot in hydroponic culture. Plant Dis. 82:1165-1170.

Glaser, B.J., J. Lehmann, and W. Zech. 2002. Ameliorating physical and chemical properties of highly weathered soils in the tropics with charcoal: A review. Biol. Fertil. Soils 35:219230 .

Graber, E.R., O. Frenkel, A.K. Jaiswal, and Y. Elad. 2015. How may biochar influence severity of disease caused by soilborne pathogens? Carbon Mgt. 5:169-183.

Graber, E.R., Y.M. Harel, M. Kolton, E. Cytryn, A. Silber, D.R. David, L. Tsechansky, 
M. Borenshtein, and Y. Elad. 2010. Biochar impact on development and productivity of pepper and tomato grown in fertigated soilless media. Plant Soil 337:481-496.

Granke, L.L., L.M. Quesada-Ocampo, K. Lamour, and M.K. Hausbeck. 2012. Advances in research on Phytophthora capsici on vegetable crops in the United States. Plant Dis. 96:15881600.

Green, V.S. and D.E. Stott. 2006. Assay for fluorescein diacetate hydrolysis activity: Optimization for soil samples. Soil Biol. Biochem. 38:693-701.

Hausbeck, M.K. and K.H. Lamour. 2004. Phytophthora capsici on vegetable crops: Research progress and management challenges. Plant Dis. 88:1292-1303.

Höper, H.C., C. Steinberg, and C. Alabouvette. 1995. Involvement of clay type and $\mathrm{pH}$ in the mechanisms of soil suppressiveness to fusarium wilt of flax. Soil Biol. Biochem. 27:955-967.

Husson, O. 2012. Redox potential (Eh) and pH as drivers of soil/plant/microorganism systems: A transdisciplinary overview pointing to integrative opportunities for agronomy. Plant Soil 362:389-417.

Jaiswal, A.K., Y. Elad, E.R. Graber, and O. Frenkel. 2014. Rhizoctonia solani suppression and plant growth promotion in cucumber as affected by biochar pyrolysis temperature, feedstock and concentration. Soil Biol. Biochem. 69:110-118.

Jones, D.L., G. Edwards-Jones, and D.V. Murphy. 2011. Biochar mediated alterations in herbicide breakdown and leaching in soil. Soil Biol. Biochem. 43:804-813.

Jupe, J., R. Stam, A.J.M. Howden, J.A. Morris, R. Zhang, P.E. Hedley, and E. Huitema. 2013. Phytophthora capsici-tomato interaction features dramatic shifts in gene expression associated with a hemi-biotrophic lifestyle. Genome Biol. 14:1-18.

Kammann, C. and E. Graber. 2015. Biochar and plant eco-physiology, p. 391-417. In: J. Lehmann and S. Joseph (eds.). Biochar for environmental management - Science and Technology. 2nd ed. Earthscan, London, UK.

Kao, C.W. and W.H. Ko. 1986. The role of calcium and microorganisms in suppression of cucumber damping-off caused by Pythium splendens in a Hawaiian soil. Phytopathology 76:221225.

Kolton, M., Y.M. Harel, Z. Pasternak, E.R. Graber, Y. Elad, and E. Cytryn. 2011. Impact of biochar application to soil on the root-associated bacterial community structure of fully developed greenhouse pepper plants. Appl. Environ. Microbiol. 77:4924-4930.

Kousik, C.S., M.L. Adams, W.R. Jester, R. Hassell, H.F. Harrison, and G.J. Holmes. 2011. Effect of cultural practices and fungicides on phytophthora fruit rot of watermelon in the Carolinas. Crop Prot. 30:888-894.

Kousik, C.S., J.L. Ikerd, P. Wechter, H. Harrison, and A. Levi. 2012. Resistance to phytophthora fruit rot of watermelon caused by Phytophthora capsici in US Plant Introductions. HortScience 47:1682-1689.

Laird, D.A. 2008. The charcoal vision: A winwin-win scenario for simultaneously producing bioenergy, permanently sequestering carbon, while improving soil and water quality. Agron. J. 100:178-181.

Laird, D.A., P. Fleming, D.D. Davis, R. Horton, B. Wang, and D.L. Karlen. 2010. Impact of biochar amendments on the quality of a typical Midwestern agricultural soil. Geoderma 158:443-449.
Lamour, K.M., R. Stam, J. Jupe, and E. Huitema. 2012. The oomycete broad-host-range pathogen Phytophthora capsici. Mol. Plant Pathol. 13:329-337.

Lehmann, J., J.P. da Silva, Jr., C. Steiner, T. Nehls, W. Zech, and B. Glaser. 2003. Nutrient availability and leaching in an archaeological Anthrosol and a Ferralsol of the Central Amazon basin: Fertilizer, manure and charcoal amendments. Plant Soil 249:343-357.

Lehmann, J., J. Gaunt, and M. Rondon. 2006. Biochar sequestration in terrestrial ecosystemsa review. Mitig. Adapt. Strategies Glob. Change 11:395-419.

Lehmann, J., M. Rillig, J. Thies, C.A. Masiello, W.C. Hockaday, and D. Crowley. 2011. Biochar effects on soil biota: A review. Soil Biol. Biochem. 43:1812-1836.

Liang, B., J. Lehmann, D. Solomon, J. Kinyangi, J. Grossman, B. O’Neill, J.O. Skjemstad, J. Thies, F.J. Luizão, J. Petersen, and E.G. Neves. 2006 Black carbon increases cation exchange capacity in soils. Soil Sci. Soc. Amer. J. 70:1719-1730.

Lumsden, L.D., R. Garcia, J.A. Lewis, and G.A. Frias. 1987. Suppression of damping-off caused by Pythium spp. in soil from indigenous Mexican chinampa agricultural system. Soil Biol. Biochem. 19:501-508.

Major, J., M. Rondon, D. Molina, S.J. Rija, and J. Lehmann. 2010. Maize yield and nutrition during 4 years after biochar application to a Columbian savanna oxisol. Plant Soil 333:117-128.

Matsubara, Y., L. Hasegawa, and H. Fukui. 2002. Incidence of fusarium root rot in asparagus seedlings infected with arbuscular mycorrhizal fungus as affected by several soil amendments. J. Jpn. Soc. Hort. Sci. 71:370-374.

Mazzola, M., D.M. Granatstein, D.C. Elfving, and K. Mullinix. 2001. Suppression of specific apple root pathogens by Brassica napus seed meal amendment regardless of glucosinolate content. Phytopathology 91:673-679.

Mehari, Z.H., Y. Elad, D. Rav-David, E.R. Graber, and Y. Meller-Harel. 2015. Induced systemic resistance in tomato (Solanum lycopersicum) against Botrytis cinerea by biochar amendment involves jasmonic acid signaling. Plant Soil 395:31-44.

Meller Harel, Y., Y. Elad, D. Rav-David, M. Borenstein, R. Shulchani, B. Lew, and E.R. Graber. 2012. Biochar mediates systemic response of strawberry to foliar fungal pathogens. Plant Soil 357:245-257.

Montanarella, L. and E. Lugato. 2013. The application of biochar in the EU: Challenges and opportunities. Agronomy 3:462-473.

Muchovej, J.J., L.A. Maffia, and R.M.C. Muchovej. 1980. Effect of exchangeable soil aluminum and alkaline calcium salts on the pathogenicity and growth of Phytophthora capsici from green pepper. Phytopathology 70:1212-1214.

Mukome, F.N., X. Zhang, L.C. Silva, J. Six, and S.J. Parikh. 2013. Use of chemical and physical characteristics to investigate trends in biochar feedstocks. J. Agr. Food Chem. 61:2196-2204.

Nerome, M., K. Toyota, T.M.D. Islam, T. Nishijima, T. Matsuoka, K. Sato, and Y. Yamaguchi. 2005. Suppression of bacterial wilt of tomato by incorporation of municipal biowaste charcoal into soil. Soil Microorganisms 59:9-14.

Novak, J.M., I. Lima, B. Xing, J.W. Gaskin, C. Steiner, K.C. Das, and H. Schomberg. 2009. Characterization of designer biochar produced at different temperatures and their effects on a loamy sand. Ann. Environ. Sci. 3:2-3.

Prendergast-Miller, M.T., M. Duvall, and S.P. Sohi. 2014. Biochar-root interactions are mediated by biochar nutrient content and impacts on soil nutrient availability. Eur. J. Soil Sci. 65:173-185.

Ristaino, J.B. and S.A. Johnston. 1999. Ecologically based approaches to management of phytophthora blight on bell pepper. Plant Dis. 83:1080-1089.

Ristaino, J.B., G. Parra, and C.L. Campbell. 1997. Suppression of Phytophthora blight in bell pepper by a no-till wheat cover crop. Phytopathology 87:242-249.

Schnitzer, M.I., C.M. Monreal, and G. Jandl. 2008. The conversion of chicken manure to bio-oil by fast pyrolysis. III. Analyses of chicken manure, bio-oils and char by Py-FIMS and Py-FDMS. J. Environ. Sci. Health B 43:81-95.

Siddiqui, Z.A. 2006. PBPR: Prospective biocontrol agents of plant pathogens, p. 111-142. In: Z.A. Siddiqui (ed.). PGPR: Bioncontrol and fertilization. Springer, Dordrecht, The Netherlands.

Singh, B.P., B.J. Hatton, B. Singh, A.L. Cowie, and A. Kathuria. 2010. Influence of biochars on nitrous oxide emission and nitrogen leaching from two contrasting soils. J. Environ. Qual. 39:1224-1235.

Spokas, K.A., K.B. Cantrell, J.M. Novak, D.W. Archer, J.A. Ippolito, H.P. Collins, A.A. Boateng, I.M. Lima, M.C. Lamb, A.J. McAloon, R.D. Lentz, and K.A. Nichols. 2011. Biochar: A synthesis of its agronomic impact beyond carbon sequestration. J. Environ. Qual. 41:973-989.

Swaine, M., R. Obrike, J. Clark, and L. Shaw. 2013. Biochar alteration of the sorption of substrates and products in soil enzyme assays. Appl. Environ. Soil Sci., doi: 10.1155/2013/968682.

Thies, J.E. and M.C. Rillig. 2009. Characteristics of biochar: Biological properties, p. 85-105. In: Biochar for environmental management. Earthscan, London, UK.

Van Zwieten, L., S. Kimber, S. Morris, K.Y. Chan, A. Downie, J. Rust, and A. Cowie. 2010. Effects of biochar from slow pyrolysis of papermill waste on agronomic performance and soil fertility. Plant Soil 327:235-246.

Ventura, M., G. Sorrenti, P. Planzacchi, E. George, and G. Tonon. 2013. Biochar reduces shortterm nitrate leaching from A horizon in an apple orchard. J. Environ. Qual. 42:76-82.

Wall, P.C., S.M. Neate, R.D. Graham, D.J. Reuter, and A.D. Rovira. 1994. The effect of rhizoctonia root disease and applied nitrogen on growth, nitrogen uptake and nutrient concentrations in spring wheat. Plant Soil 163:111120.

Wang, Y., F. Pan, G. Wang, G. Zhang, Y. Wang, X. Chen, and Z. Mao. 2014. Effects of biochar on photosynthesis and antioxidative system of Malus hupehensis Rehd. Seedlings under replant conditions. Sci. Hort. 175:9-15.

Watts, C.W., W.R. Whalley, P.C. Brookes, B.J. Devonshire, and A.P. Whitmore. 2005. Biological and physical processes that mediate microaggregation of clays. Soil Sci. 170:573-583.

Ye, S.F., J.Q. Yu, Y.H. Peng, J.H. Zheng, and L.Y. Zou. 2004. Incidence of Fusarium wilt in Cucumis sativus J. is promoted by cinnamic acids, and autotoxin in root exudates. Plant Soil 263:143-150.

Zhang, S., T.L. White, M.C. Martinez, J.A. McInroy, J.W. Kloepper, and W. Klassen. 2010. Evaluation of plant growth-promoting rhizobacteria for control of phytophthora blight on squash under greenhouse conditions. Biol. Control 53:129-135.

Zwart, D.C. and S.H. Kim. 2012. Biochar amendment increases resistance to stem lesions caused by Phytophthora spp. in tree seedlings. HortScience 47:1736-1740. 